\title{
Standing with those who seek justice
}

\section{Ruth E Malone}

Each time I read a news report about a lawsuit filed against tobacco companies, or a jury award in such a case, I salute the courage and tenacity of those individuals and families who continue to carry the tobacco battle forward in the courtroom. Of course, the lawyers deserve credit as well, and there are many others among the global tobacco control community who have contributed time and expertise to such cases, sometimes at considerable personal sacrifice. But given the enormous physical, financial and personal burdens plaintiffs face in going up against the industry's armies of well-paid lawyers and their investigators and consultants, who leave no stone unturned in excavating the personal pasts of plaintiffs and trying to excoriate them in court, it is truly an act of exceptional courage for those who bring these cases to carry on.

A few months ago, Dr Howard Engle died of chronic obstructive lung disease. He was the Miami Beach paediatrician whose tobacco lawsuit accusing tobacco companies of knowingly addicting people and failing to warn them of the dangers of continuing to smoke resulted in the largest punitive damage award in US history. A Florida jury awarded \$145 billion (£89 billion; $€ 102$ billion) in punitive damages against tobacco companies in 2000 .

Although the verdict was later overturned, the case inspired others, and the legal process led to more cases brought by individuals harmed by tobacco products. I stand with Dr Engle's family.

This week, a jury awarded $\$ 5.3$ million to 92-year-old Leon Barbanell of Florida, whose wife, Shirley, died with chronic obstructive pulmonary disease and lung

Correspondence to: Ruth E Malone, Editor, Tobacco Control; ruth.malone@ucsf.edu cancer after smoking Marlboros for some 40 years. It is the sixth verdict for the plaintiffs in the set of thousands of lawsuits known as the Engle progeny. Of course, endless appeals are likely, as tobacco companies continue to argue in court that plaintiffs are responsible for their disease, or (as Philip Morris tried to argue in the Barbanell case) that they did not have or did not die from the disease, or that if they had the disease, it was the result of some other cause besides ordinary use of the company's products. And the awarded amounts are still chump change for multinationals. I stand with the Barbanell family.

The day I write this, a jury decided that cigarette maker Philip Morris USA should pay $\$ 13.8$ million in punitive damages to Jodie Bullock, the daughter of Betty Bullock, who died of lung cancer in 2003. I stand with Jodie Bullock. In so many cases, it is the families who continue to pursue justice on behalf of their loved ones, while the companies continue year after year to obstruct and deny, promoting to new generations the same deadly products that have killed Howard, Shirley, Betty, and millions of others.

While to date, most of the legal cases are in the United States, there are courageous challengers in other countries, including Japan, where the government itself still is a major owner of Japan Tobacco. Since 2005, when their case began, plaintiff Kenichi Morishita has died of pneumonia and bacterial infection, leaving 67-year-old cancer patient Koreyoshi Takahashi and Masanobu Mizuno, 67 and suffering from emphysema, to continue the fight. They hope that even if they lose, their case will draw more attention to the harmfulness of cigarettes. I stand with the Morishita family, and with Koreyoshi Takahashi and Masanobu Mizuno.

In Poland, Stanisław Lubicz-Sienicki is suing tobacco firms for damages related to the death of his mother, who died of lung cancer earlier this year. I stand with Stanislaw Lubicz-Sienicki. In Israel, a class action lawsuit is moving ahead on behalf of a mother who died at 47 from lung cancer after becoming addicted to menthol cigarettes. I stand with the family of that mother, whose name was not listed in the report. I stand with the Cippolone family, with Mayola Williams, with the family of Leslie Whitely, with all those unnamed here who take on the tobacco companies. Some day we will look back on their sacrifices and realise what groundbreaking work they did, opening the first cracks in the tobacco industry's previously solid wall of denial.

Having cared for many patients who suffered terribly from tobacco-caused diseases before dying, I know that continuing a lawsuit while battling for each breath, trying to stay focused while in excruciating pain must be exhausting. Yet those who seek justice do it. They go on. They go on in the face of scorn from tobacco industry lawyers, and sometimes from former friends who do not understand the nature of addiction and the scale of the deceptions perpetrated by tobacco companies. They do it on behalf of their families, on behalf of those before them whose lives were sacrificed to tobacco company profits, and on behalf of those coming after, for whom they seek a better world: a world in which, perhaps, companies would not knowingly promote deadly and addictive products. A world in which, perhaps, those who had done so would be held accountable at last. A just world.

Competing interests: Ruth Malone served as a tobacco industry documents consultant for the United States Department of Justice in USA vs Philip Morris et al.

Provenance and peer review: Commissioned; not externally peer reviewed.

Tobacco Control 2009;18:337.

doi:10.1136/tc. 2009.033530 